\title{
PENERAPAN METODE SERVICE QUALITY \& QUALITY FUNCTION DEPLOYMENT (QFD) DALAM UPAYA PENINGKATAN PELAYANAN KEPADA MAHASISWA POLITEKNIK KETAPANG
}

\author{
Muh Anhar ${ }^{1}$,Syarifah Umi Kalsum ${ }^{2}$ \\ Departemen Perawatan Dan Perbaikan Mesin ${ }^{1}$,Departemen Teknik Pertambangan ${ }^{2}$ \\ Politeknik Negeri Ketapang \\ Jl.Rangga Sentap Dalong Sukaharja Ketapang \\ Email: anhar_dol@yahoo.com ${ }^{1}$ \\ Email: syarifahumi99kalsum@gmail.com ${ }^{2}$
}

\begin{abstract}
Abstrak. Penggunaan Servqual dan QFD untuk mengidentifikasi keinginan dan kebutuhan mahasiswa jurusan Perawatan Dan Perbaikan Mesin Politeknik Ketapang serta upaya peningkatan mutu layanan meliputi: penentuan atribut layanan, pembuatan kuesioner, pengumpulan dan pengolahan data, pembuatan HOQ, analisa dan Interprestasi dan identifikasi upaya perbaikan kualitas layanan. Dari hasil penelitian diperoleh servqual-gap secara berurutan adalah: Assurance (-1,491), Empathy (-1,462), Responsiveness (-1,459), Reliability $(-1,457)$ dan Tangibles $(-1,422)$. Hal ini berarti mahasiswa menaruh harapan sangat besar akan pelayanan yang baik dari lembaga. Namun demikian masih ada kesenjangan antara kualitas layanan yang diharapkan oleh mahasiswa dan tingkat kebaikan pelayanan yang diberikan sehingga belum sepenuhnya seperti yang diharapkan. Perbaikan dan peningkatan kualitas layanan sangat mungkin dilakukan mengingat improvement ratio nya sebesar 1,188 (Moderately Difficult Improvement) yang berarti sumber daya yang dimiliki oleh Jurusan perawatan dan perbaikan mesin Politeknik Ketapang mampu menunjangnya dengan baik.
\end{abstract}

\section{Kata Kunci: mahasiswa, tingkat kepuasan, Servqual, House of Quality}

Abstract. Use of Servqual and QFD to identify desire and requirement of maintenance and repair machinery of Politeknik Ketapang and the effort improvement the service of quality cover: determination of service attribute, making quesioner, gathering and data processing, making $H O Q$, analyse and Interprestasi, identify effort of repair service quality. As for its servqual-gap alternately: Assurance (- 1.491), Empathy (- 1.462), Responsiveness (- 1.459), Reliability (- 1.457) and Tangibles (- 1.422). Matter of this means student put expectation very big the service will be good from institute. But that way the difference there be still among service quality expected by student and mount service kindliness given so th at not yet full is such as those which expected. Applying QFD by House of Quality emphasize existence repair and improvement at five dimension of service quality in sequence above mentioned. This improvement and repair is very possible conducted to remember its improvement ratio equal to 1.188 (Moderately Difficult Improvement) meaning resource owned by maintenance and repair machinery of Politeknik Ketapang able to support it better.

Keyword: student, mount satisfaction, Servqual, House of Quality 


\section{Pendahuluan}

Dalam upaya meningkatkan kualitas layanan di Politeknik Ketapang khususnya di Jurusan perawatan dan perbaikan mesin terlebih dahulu harus dianalisa apakah layanan yang dilakukan saat ini sudah sesuai dengan harapan mahasiswa. Untuk mengetahui hal ini, diperlukan suatu study kualitas layanan kepada mahasiswa selaku pelanggan primer. Peningkatan kualitas pelayanan ini dapat dilakukan dengan menggunakan metode Service Quality (SERVQUAL). Servqual adalah suatu alat untuk mengukur kualitas layanan dimana nilainya diperoleh dengan mencari selisih antara nilai persepsi dengan nilai harapan. Metode ini dikembangkan oleh, A.Parasuraman,Valarei A.Zeithaml, dan Leonard L.Berry (1994).

Pengukuran kualitas layanan dengan SERVQUAL seyogyanya diikuti dengan aplikasi Quality Function Deployment (QFD) guna memperjelas action plan yang harus dilakukan untuk memperkecil kesenjangan/gap yang terjadi (Fitri dan Patdono 2006). Hubungan antara kedua metode itu adalah dengan memanfaatkan gap persepsi dan harapan, hasil pengukuran SERVQUAL, menjadi level of importance pada House of Quality (HOQ) atau rumah mutu yang menjadi bagian dari QFD tersebut.Proses QFD berusaha dapat menterjemahkan kebutuhan konsumen (dalam hal ini mahasiswa) ke seluruh organisasi melalui House of Quality (HOQ). HOQ merupakan suatu matriks yang bertujuan untuk mengidentifikasi atau mengevaluasi kebutuhankebutuhan konsumen dengan kebutuhan teknis produk (Ciptono, 1999 :6).

Rumusan dalam penelitian iniadalah penggunaan metode Service Quality dan Quality Function Deploymentserta upaya yang harus dilakukan oleh jurusan Perawatan dan Perbaikan Mesin politeknik Negeri Ketapang dalam ussaha untuk meningkatkan pelayanan yang diharapkan oleh mahasiswa.

\section{Landasan Teori}

\subsection{Pengertian Jasa/layanan}

Menurut Kotler (1997), jasa adalah setiap tindakan atau perbuatan yang dapat ditawarkan oleh suatu pihak kepada pihak lain yang pada dasarnya tidak berwujud fisik (intangible) dan tidak menghasilkan kepemilikan sesuatu.

\subsection{Kualitas Jasa (Service Quality)}

Menurut Wyckof (dalam Lovelock, 1988), kualitas jasa adalah tingkat keunggulan yang diharapkan dan pengendalian atas tingkat keunggulan tersebut untuk memenuhi keinginan pelanggan. Ada dua faktor utama yang mempengaruhi kualitas jasa, yaitu expected service dan perceived service. Apabila jasa yang diterima atau dirasakan (perceived service) sesuai dengan yang diharapkan (expected service), maka kualitas jasa dipersepsikan baik dan memuaskan. Jika jasa yang diterima melampaui harapan pelanggan, maka kualitas jasa dipersepsikan ideal. Sebaliknya jika jasa yang diterima lebih rendah daripada yang diharapkan, maka kualitas jasa dipersepsikan buruk (Parasuraman, 1990). Kualitas harus dimulai dari kebutuhan pengguna dan berakhir pada persepsi pengguna tersebut (Kotler, 1994).

\subsection{Dimensi Pokok Kualitas Jasa}

Terdapat lima dimensi pokok yang umum digunakan untuk mengidentifikasi kualitas jasa layanan (Tjiptono, 2004 : 69):

1. Tangibles (bukti langsung): Ketersediaan fasilitas fisik, perlengkapan, sumber daya manusia dan sarana penunjang.

2. Reliability (keandalan): Kemampuan dan kemauan lembaga dalam memberikan pelayanan yang handal, terpercaya dan memuaskan.

3. Responsiveness (daya tanggap): Kemampuan dan kemauan dari seluruh lini manajemen untuk membantu memenuhi kebutuhan konsumen dengan cepat.

4. Assurance (jaminan): Keramahan dan kemampuan yang dimiliki seluruh lini manajemen dalam melaksanakan tugasnya.

5. Empathy(empati): Sikap peduli dan membangun kemudahan komunikasi serta pemahaman yang baik terhadap kebutuhan konsumen.

\subsection{Pengukuran Kualitas Jasa}

Mengukur kualitas jasa berarti mengevaluasi atau membandingkan kinerja suatu jasa dengan seperangkat standar yang telah ditetapkan terlebih dahulu. Alat ukur yang sering digunakan adalah sebuah skala multi item yang diberi nama SERVQUAL (Service Quality). Alat ini dimaksudkan untuk mengukur harapan dan persepsi pelanggan serta kesenjangan (gap) yang ada pada model kualitas jasa. Pengukuran dapat dilakukan dengan skala Likert maupun skala Thurstone.

\subsection{Quality Function Deployment(QFD) \\ 2.5.1 Pengertian QFD}

Lou Cohen (1995 : 11) memberi pengertian: "QFD adalah sebuah metodologi untuk pengembangan dan perencanaan produk yang memungkinkan tim pengembangan untuk menspesifikasikan secara jelas kebutuhan dan keinginan pelanggan kemudian mengevaluasi setiap produk yang ditawarkan atau kemampuan pelayanan secara sistematis dengan melihat bentuk dari pertemuan kebutuhan-kebutuhan tersebut." Tujuan QFD adalah memenuhi sebanyak mungkin harapan konsumen, demi kepuasan konsumen.

\subsubsection{Implementasi QFD}

Implementasi QFD secara garis besar dibagi dalam 3 tahap (Cohen, 1995):

1. Tahap Perencanaan dan Persiapan

2. Tahap pengumpulan Voice of customer

3. Tahap penyusunan house of quality

4. Tahap Analisa dan Interpretasi 


\section{Bahan Dan Metodologi Penelitian}

\subsection{Konsep Dasar}

Citra kualitas layanan yang baik bukanlah berdasarkan sudut pandang atau persepsi pihak penyedia jasa. layanan, melainkan berdasarkan sudut pandang atau persepsi mahasiswa tersebut. Persepsi mahasiswa terhadap kualitas layanan merupakan penilaian menyeluruh atas keunggulan suatu layanan terutama layanan akademik dan layanan administratif.

\subsection{Penggunaan Servqual dan QFD}

1. Menentukan atribut layananan (data kualitatif) dari model Servqual

2. Membuat kuesioner model Servqual

3. Pengumpulan dan pengolahan data kuantitatif model Servqual

4. Pembuatan House of Quality (HOQ)

5. Analisa dan Interprestasi

6. Hasil interprestasi HOQ menunjukkan target perbaikan kualitas pelayanan yang harus dilakukan dengan melihat rangking target.

7. Mengidentifikasi upaya-upaya perbaikan kualitas layananan kepada mahasiswa Jurusan perawatan dan perbaikan mesin.

\subsection{Bahan dan Alat Ukur}

\section{a. Bahan Penelitian}

Populasi penelitian ini adalah mahasiswa Jurusan perawatan dan perbaikan mesin Politeknik Ketapang yang masih aktif kuliah dan saat ini duduk di tingkat akhir dan sebagian alumni.

b. Alat Ukur Penelitian

Alat ukur penelitian berbentuk angket, dengan tingkat pengukuran ordinal. Skala likert untuk mengukur persepsi, harapan konsumen, dan tingkat kepentingan yang diperlukan.

Tabel 4.2 Skala Likert Kepentingan / Harapan

\begin{tabular}{|l|c|}
\hline \multicolumn{1}{|c|}{ Jawaban } & Skala Likert \\
\hline Sangat Tidak Penting (STP) & 1 \\
\hline Tidak Penting (TP) & 2 \\
\hline Cukup Penting (CP) & 3 \\
\hline Penting (P) & 4 \\
\hline Sangat Penting (SP) & 5 \\
\hline
\end{tabular}

Tabel 4.3 Skala Likert untuk kondisi yang dialami

\begin{tabular}{|l|c|}
\hline \multicolumn{1}{|c|}{ Jawaban } & Skala Likert \\
\hline Sangat Tidak Baik (STB) & 1 \\
\hline Tidak Baik (TB) & 2 \\
\hline Cukup Baik (CB) & 3 \\
\hline Baik (B) & 4 \\
\hline Sangat Baik (SB) & 5 \\
\hline
\end{tabular}

\subsection{Metode Penelitian}

Penelitian ini dilakukan dengan menggunakan metode menyebarkan kuisioner terhadap mahasiswa mahasiswa Jurusan perawatan dan perbaikan mesin Politeknik Ketapang yang masih aktif kuliah yang saat ini duduk di tingkat akhir dan sebagian alumni untuk mengeetahui tingkat kepuasan dan harapan yang diinginkan mahasiswa baik yang aktif ataupun alumni.

\section{Hasil dan Pembahasan}

4.1. Hasil

Sampel sumber data berjumlah 100 orang, terdiri atas mahasiswa semester VI dan alumni. Data yang dikumpulkan bersifat kualitatif, berupa informasi mengenai atribut pelayanan yang terdapat di Jurusan perawatan dan perbaikan mesin melalui kuesioner awal dan wawancara yang mengacu Servqual.

1. Tangible (Tampilan) yang meliputi fasilitas fisik, gedung, perlengkapan, penampilan pegawai (karyawan dan dosen), kelengkapan sarana pendukung, tersediaannya tempat parkir, kebersihan, kerapian dan kenyamanan.

2. Reliability (Keterpercayaan) yaitu kemampuan untuk memberikan pelayanan yang sesuai dengan yang dijanjikan dengan segera atau tepat waktu, akurat dan memuaskan. Hal ini meliputi persoalan pemberian mata kuliah yang benar-benar sesuai dengan kebutuhan, jujur, tepat waktu, dan selalu siap melayani mahasiswa.

3. Responsiveness (Ketanggapan) yaitu keinginan, respon atau kesigapan pihak Jurusan perawatan dan perbaikan mesindalam membantu mahasiswa dan memberikan pelayanan yang cepat dan tanggap. Sikap-sikap tanggap yang dapat menimbulkan persepsi positif dari mahasiswa, misalnya kemudahan menemui dosen untuk konsultasi, bimbingan, proses belajar mengajar yang interaktif. Selain itu fasilitas layanan yang ada harus mudah diakses oleh setiap civitas akademika, apabila ada peralatan yang rusak cepat diperbaiki sehingga selalu siap digunakan.

4. Assurance (Jaminan) mencakup pengetahuan, kompetensi/ kemampuan, dan sifat dapat dipercaya yang dimiliki pihak Jurusan Perawatan dan Perbaikan, bebas dari keragu-raguan. Dalam hal ini jajaran dosen dan karyawan harus benarbenar kompeten di bidangnya, memiliki reputasi positif, dan sikap serta perilaku yang mencerminkan profesionalisme.

5. Empathy (empati) meliputi kemudahan dalam melakukan interaksi, komunikasi yang baik, perhatian dan selalu memahami kebutuhan mahasiswa. Dalam hal ini dosen pembimbing akademik dapat benar-benar berperan sesuai fungsinya, setiap dosen dapat dihubungi dengan mudah, baik di ruang kerja, via telepon maupun email.

\subsubsection{Pengujian Instrumen}

a. Uji validasi dan Reliabilitas

Hasil perhitungan validitas dan reliabilitas tingkat dan kepentingan dan kepuasan (persepsi) dapat dilihat pada tabel berikut ini:

Tabel 5.1 Uji Validitas

\begin{tabular}{|l|c|c|c|}
\hline Tingkat & $\mathrm{r}_{11}$ Hitung & $\mathrm{r}$ Tabel & Ket. \\
\hline \hline Harapan & 0,57920 & 0,1974 & Valid \\
\hline Persepsi & 0,46597 & 0,1974 & Valid \\
\hline \multicolumn{4}{|c|}{ Tabel 5.2 Uji Reliabilitas } \\
\hline Tingkat & r $_{11}$ Hitung & r Tabel & Ket. \\
\hline \hline Harapan & 0,94231 & 0,1962 & Reliabel \\
\hline Persepsi & 0,96885 & 0,1962 & Reliabel \\
\hline
\end{tabular}




\subsection{Pembahasan}

\subsubsection{Analisis dengan Diagram Radar}

Diagram ini menggambarkan titik-titik yang berbentuk seperti radar, bila tidak terhubung dengan seimbang atau menunjukkan titik yang semakin memusat maka berarti terjadi masalah pada beberapa faktor atau dimensi yang di teliti.

a. Diagram Radar Nilai Persepsi dan Harapan

Tabel 5.3Nilai Persepsi dan Harapan

\begin{tabular}{|c|c|c|}
\hline Dimensi & P & H \\
\hline Tangibles & 4,36 & 2,94 \\
\hline Reliability & 4,51 & 3,06 \\
\hline Responsiv. & 4,53 & 3,07 \\
\hline Assurance & 4,62 & 3,13 \\
\hline Empathy & 4,58 & 3,12 \\
\hline
\end{tabular}

Sumber: Hasil Pengolahan Data

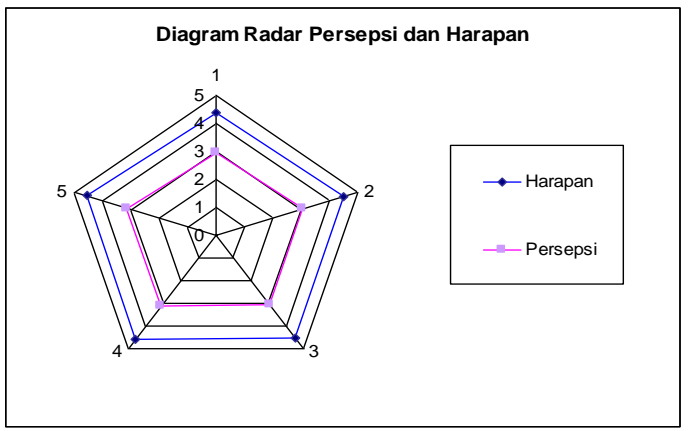

Gambar 5.1 Diagram Radar Harapan dan Persepsi Nilai rata-rata persepsi mahasiswa Jurusan perawatan dan perbaikan mesinterhadap layanan yang diberikan masih terletak dibawah nilai rata-rata harapan mahasiswa tersebut.

b. Diagram Radar Persepsi Item Pertanyaan

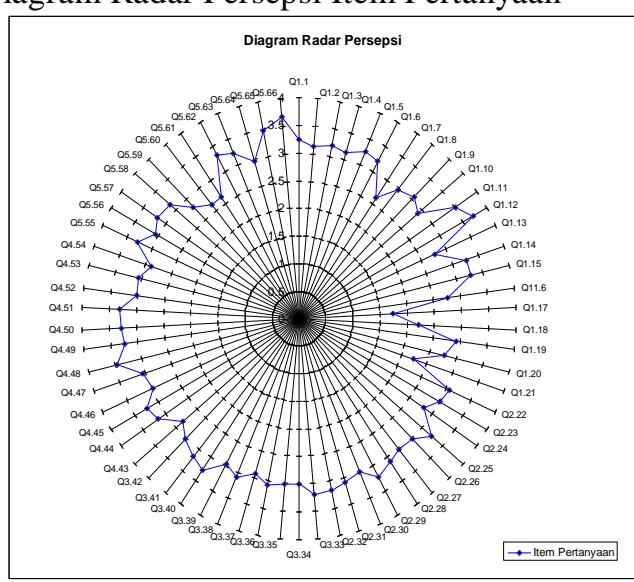

Gambar 5.2. Diagram radar persepsi mhs

Untuk persepsi yang memiliki rata-rata kurang dari 3 sebanyak 23 atribut yaitu pada item pertanyaan Q1.7, Q1.8, Q1.10, Q1.13, Q1.16, Q1.17, Q1.18, $\mathrm{Q} 1.19, \mathrm{Q} 1.20, \mathrm{Q} 1.21, \mathrm{Q} 2.23, \mathrm{Q} 2.24, \mathrm{Q} 2.27, \mathrm{Q} 2.30$, Q3.37, Q3.39, Q4.43, Q4.46, Q4.54, Q5.59, Q5.60, Q5.61, Q5.64 mempunyai skor dibawah 3 ini artinya pelayanan yang selama ini dirasakan mahasiswa dirasa belum memenuhi kepuasan dan kebutuhannya.

\subsubsection{Analisis Pembuatan HOSQ \\ a. Importance to Customer}

Tabel 5.4. Importance to Customer

\begin{tabular}{|c|l|c|}
\hline No. & \multicolumn{1}{|c|}{ Dimensi } & Skor \\
\hline \hline 1 & Assurance & \\
\hline 2 & Empathy & \\
\hline 3 & Responsiveness & \\
\hline 4 & Reliability & 4,6008 \\
\hline 5 & Tangible & \\
\hline & Rata-rata & \\
\hline
\end{tabular}

Hasil perhitungan tingkat kepentingan rata-rata atribut yang didapat dari perhitungan kuesioner adalah sebesar 4,499 yang berarti semua atribut yang terkandung dalam lima dimensi kualitas pelayanan adalah di atas kualifikasi penting.

b. Tingkat Kebaikan Pelayanan di Jurusan

Dari perhitungan diperoleh tingkat kebaikan layanan sebagaimana pada tabel 5.5:

Tabel 5.5 Tingkat Kepuasan Mahasiswa

\begin{tabular}{|c|l|c|}
\hline No. & \multicolumn{1}{|c|}{ Dimensi } & Skor \\
\hline 1 & Assurance & 3,127 \\
\hline 2 & Empathy & 3,116 \\
\hline 3 & Responsiveness & 3,067 \\
\hline 4 & Reliability & 3,057 \\
\hline 5 & Tangible & 2,942 \\
\hline & Rata-rata & 3,045 \\
\hline
\end{tabular}

Tabel 5.6Klasifikasi Kepuasan Layanan

\begin{tabular}{|c|c|c|}
\hline No. & Rentang Gap & Kategori \\
\hline 1 & $4,01 \mathrm{~s} / \mathrm{d}-5,00$ & Sangat Puas \\
\hline 2 & $3,01 \mathrm{~s} / \mathrm{d}-4,00$ & Puas \\
\hline 3 & $2,01 \mathrm{~s} / \mathrm{d}-3,00$ & Cukup Puas \\
\hline 4 & $1,01 \mathrm{~s} / \mathrm{d}-2,00$ & Kurang Puas \\
\hline 5 & 0,01 s/d $-1,00$ & Tidak Puas \\
\hline
\end{tabular}

Hasil perhitungan tingkat kebaikan customer requirement berdasar penilaian mahasiswa terhadap lima dimensi kualitas pelayanan, rata-rata sebesar 3,045 . Ini berarti berarti pelayanan Jurusan perawatan dan perbaikan mesin relatif baik dan sudah memuaskan mahasiswa.

\section{c. Target Pelayanan dengan Tingkat Kepentingan Relatif}

Tabel 5.7Target Kualitas Pelayanan

\begin{tabular}{|c|l|c|c|}
\hline No & Dimensi & Skor Riil & Skor Target \\
\hline \hline 1 & Tangible & 2,942 & 3,476 \\
\hline 2 & Reliability & 3,057 & 3,636 \\
\hline 3 & Responsiv & 3,067 & 3,700 \\
\hline 4 & Assurance & 3,127 & 3,750 \\
\hline 5 & Empathy & 3,116 & 3,667 \\
\hline
\end{tabular}

Berdasarkan tabel 5.7, target peningkatan pelayanan Jurusan perawatan dan perbaikan mesin per dimensi kualitas pelayanan lebih tinggi dari pada kualitas pelayanan yang dilakukan sekarang.

\section{d. Rasio Perbaikan (Improv- Ratio)}

Rasio perbaikan ini dimaksudkan untuk mengetahui apakah item-item dalam dimensi kualitas 
pelayanan di Jurusan perawatan dan perbaikan mesin dapat dilakukan atau tidak.

Tabel 5.8Improvement Ratio (IR)

\begin{tabular}{|c|l|c|}
\hline No. & \multicolumn{1}{|c|}{ Dimensi } & Skor \\
\hline \hline 1 & Tangible & 1,183324 \\
\hline 2 & Reliability & 1,186666 \\
\hline 3 & Responsiveness & 1,204107 \\
\hline 4 & Assurance & 1,197185 \\
\hline 5 & Empathy & 1,175272 \\
\hline & Rata-rata & 1,188086 \\
\hline
\end{tabular}

Kategori Improvement Ratio dapat diklasifikasi dalam 3 golongan (Cohen 1995), yaitu:

\begin{tabular}{|c|c|}
\hline Nilai IR & Keterangan \\
\hline 1 & No Change \\
\hline 1,2 & Moderately Difficult Improvement \\
\hline 1,5 & Difficult Improvement \\
\hline
\end{tabular}

Pada tabel 5.8 diperoleh rata-rata Improvement Ratio sebesar 1,188086. Hal ini berarti bahwa secara umum perbaikan kualitas pelayanan dapat dilakukan sebab besaran Improvement Ratio-nya berada pada pengembangan tingkat hambatannya bersifat moderat.

\section{e. Kebutuhan Teknis Pelayanan (Technical} Requirement) pada Unit-unit Pelayanan

Penentuan Technical Requirement dalam HOSQ ini merupakan penterjemahan customer requirement ke dalam unit-unit pelayanan (design requirement) yang ditunjukkan dengan job description dari masingmasing bagian yang terlibat dalam pelayanan jasa administrasi dan jasa akademik kepada mahasiswa Jurusan perawatan dan perbaikan mesin.

\section{f. Bobot Mentah (Raw Weight) dan Bobot Bersih (Net Weight)}

Hasil perhitungan cumulative normalized raw weight (CNRW) dapat dilihat pada tabel 5.11

Tabel 5.11 Cumulative Normalized Raw Weight

\begin{tabular}{|c|l|c|}
\hline No. & \multicolumn{1}{|c|}{ Dimensi } & CNRW \\
\hline \hline 1 & Tangible & 0,307294 \\
\hline 2 & Reliability & 0,167051 \\
\hline 3 & Responsiveness & 0,154659 \\
\hline 4 & Assurance & 0,187861 \\
\hline 5 & Empathy & 0,183135 \\
\hline
\end{tabular}

Atribut kualitas pelayanan Jurusan perawatan dan perbaikan mesin masih didominasi unsur Tangible (30,73\%), Assurance (18,79\%), Empathy (18,31\%), Reliability $(16,70 \%)$ dan Responsiveness $(15,46 \%)$.

\section{g. Keeratan Hubungan antara Customer Requirement dan Design Requirement}

Penentuan hubungan keeratan antara Komponen Customer Requirement dan Komponen Design Requirement dilakukan dengan para pengelola unit pelayanan di Politeknik Ketapang. Keeratan hubungan ini dapat digolongkan dalam empat klasifikasi, yaitu:

\begin{tabular}{|c|c|l|}
\hline Simbol & Numerik & \multicolumn{1}{c|}{ Pengertian } \\
\hline Kosong & 0 & Tidak ada hubungan \\
\hline $\boldsymbol{\Delta}$ & 1 & Mungkin ada hub. \\
\hline $\boldsymbol{O}$ & 3 & Hubunga sedang \\
\hline $\boldsymbol{\Theta}$ & 9 & Hub sangat kuat \\
\hline
\end{tabular}

\section{h. Matriks Korelasi Design Requirement}

Matriks korelasi menggambarkan hubungan di antara setiap unit Design Requirement yang penilaiannya didasarkan atas diskusi dengan para pengelola unit pelayayanan di Politeknik Ketapang. Matriks korelasi ini letaknya di bagian atas (atap) dari matriks HOSQ. Hubungan di antara setiap unit Design Requirement ini dapat digolongkan menjadi dua, yaitu:

1. Hubungan Sinergi, yaitu hubungan di antara setiap unit Design Requirement saling mendukung dalam pemenuhan Customer Requirement..

2. Hubungan Konflik, yaitu hubungan di antara setiap unit Design Requirement mengalami pertentangan dalam pemenuhan Customer Requirement.

\subsubsection{Bentuk HOSQ secara Keseluruhan.}

Gambar HOSQ berdasrkan hasil analisis lima dimensi kualitas pelayanan kepada mahasiswa di Jurusan perawatan dan perbaikan mesin ditunjukkan dalam gambar 5.1

\subsubsection{Spesifikasi Ranking Mutu Layanan}

Spesifikasi ini dibuat dengan cara meranking semua item dalam setiap dimensi pelayanan berdasarkan tingkat mutu layanan. Dengan demikian sebelum Jurusan perawatan dan perbaikan mesin menentukan kebijakan-kebijakan untuk peningkatan kualitas layanan kepada mahasiswa, maka perlu diketahui gap kualitas pelayanan. Untuk gap rata-rata setiap dimensi dimensi dapat dilihat pada tabel 5.12.

Tabel 5.12Gap Kualitas Pelayanan

\begin{tabular}{|l|c|c|c|}
\hline \multicolumn{1}{|c|}{ Dimensi } & Harapan & Kondisi & Gap \\
\hline \hline Assurance & 4,618 & 3,127 & $-1,491$ \\
\hline Empathy & 4,578 & 3,116 & $-1,462$ \\
\hline Responsiv. & 4,526 & 3,067 & $-1,459$ \\
\hline Reliability & 4,514 & 3,057 & $-1,457$ \\
\hline Tangible & 4,364 & 2,942 & $-1,422$ \\
\hline
\end{tabular}

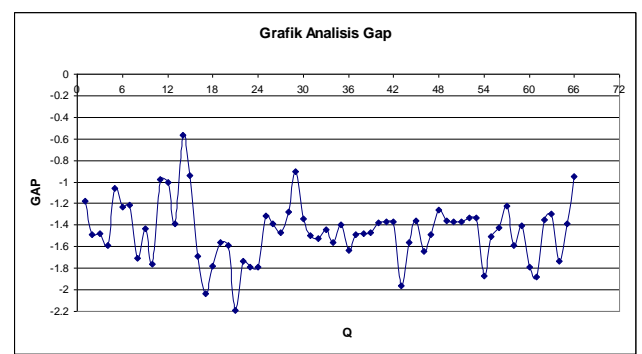

Gambar 5.2 Grafik Gap Pelayanan JTPPM

Tabel 5.14 Klasifikasi Kualitas Layanan

\begin{tabular}{|c|c|c|}
\hline No. & Rentang Gap Skor & Kategori \\
\hline 1 & $>0,50$ & Sangat Baik \\
\hline 2 & $0,50 \mathrm{~s} / \mathrm{d}-0,50$ & Baik \\
\hline 3 & $-0,51$ s/d $-2,00$ & Cukup Baik \\
\hline 4 & $-2,01$ s/d - 3,50 & Kurang Baik \\
\hline 5 & $-3,51$ s/d $-5,00$ & Tidak Baik \\
\hline
\end{tabular}




\subsubsection{Analisis Kepentingan dan Gap Kualitas Layanan perdimensi \\ 1. Assurance}

Dimensi kualitas pelayanan ini mencakup pengetahuan, kompetensi dan sifat dapat dipercaya serta bebas dari keragu-raguan yang dimiliki pihak Jurusan Perawatan dan Perbaikan. Jajaran dosen dan karyawan harus benar-benar kompeten di bidangnya, memiliki reputasi positif, dan sikap serta perilaku yang mencerminkan profesionalisme. Penekanan dimensi ini terletak pada kemampuan lembaga untuk meningkatkan image sehingga dapat memberikan reputasi yang baik kepada institusi dan mahasiswa serta memberikan jaminan mutu lulusan bagi pengguna lulusan tersebut.

Hasil perhitungan menunjukkan bahwa tingkat kepentingan atribut ini adalah sebesar 4,618, tingkat kebaikan atribut sebesar 3,127. Adapun gap kualitas pelayanan untuk dimensi ini adalah sebesar -1,491 (Tabel 5.12). Ini semua berarti bahwa bahwa kualitas pelayanan untuk dimensi ini sudah cukup memuaskan. Kendatipun demikian masih ada sebagian atribut kualitas layanan dimensi yang belum dapat di penuhi.

\section{Empathy}

Dimensi kualitas pelayanan ini meliputi kemudahan dalam melakukan interaksi, komunikasi yang baik, perhatian dan selalu memahami kebutuhan mahasiswa.

Dengan demikian penekanan dimensi ini adalah peningkatan hubungan, sikap baik dan perhatian dari pengelola karyawan dan dosen kepada mahasiswa.

Hasil perhitungan menunjukkan bahwa tingkat kepentingan atribut ini menurut penilaian mahasiswa adalah sebesar 4,578, sedangkan tingkat kebaikan atribut ini adalah sebesar 3,116. jadi gap kualitas pelayanan untuk dimensi ini adalah sebesar $-1,462$. Hal ini berarti bahwa kualitas pelayanan untuk dimensi ini adalah cukup memuaskan. Kendatipun demikian sebenarnya baru sebagian saja atribut kualitas layanan dimensi emphaty yang dapat di penuhi.

\section{Responsiveness}

Atribut kualitas pelayanan responsiveness berkaitan dengan keinginan, respon atau kesigapan pihak Jurusan dalam membantu mahasiswa dan memberikan pelayanan secara cepat dan tanggap. Penekanan dimensi ini ialah peningkatan kemauan dan kecepatan dalam memberikan pelayanan kepada mahasiswa secara tepat waktu. Hal terpenting pemanfaatan waktu se-efisien dan sebaik mungkin untuk melakukan pelayanan kepada mahasisiwa.

Yang sering terjadi adalah penundaan hal-hal yang semestinya bisa dilakukan saat itu.

Hasil perhitungan menunjukkan bahwa tingkat kepentingan atribut ini menurut penelitian terhadap mahasiswa adalah sebesar 4,526 sedangkan tingkat kebaikan atribut ini adalah sebesar 3,067. Jadi gap kualitas pelayanan untuk dimensi ini adalah sebesar 1,459. Hal ini berarti kualitas pelayanan untuk dimensi ini adalah cukup memuaskan. Hal ini berarti pula baru sebagian saja atribut kualitas layanan dimensi responveness yang dapat dipenuhi.

\section{Reliability}

Atribut pelayanan Reliability meliputi kemampuan untuk memberikan pelayanan yang sesuai dengan yang dijanjikan dengan segera atau tepat waktu, akurat dan memuaskan. Dimensi ini menekankan kemampuan dan kemauan lembaga untuk memberikan pelayanan sesuai di janji dengan handal dan memuaskan.

Hasil perhitungan memperlihatkan bahwa tingkat kepentingan atribut menurut mahasiswa rata-rata sebesar 4,514, tingkat kebaikan atribut tersebut ratarata sebesar 3,057. jadi gap untuk dimensi pelayanan ini adalah sebesar -1,457. Hal ini berarti bahwa kualitas pelayanan di Jurusan perawatan dan perbaikan mesin hanya berkisar cukup baik. Meskipun demikian apa yang diharapkan oleh mahasiswa belum dapat dipenuhi sepenuhnya.

\section{Tangible}

Dimensi kualitas layanan tangibles ini berkaitan dengan keberadaan sarana fisik untuk menunjang kegiatan utama proses belajar mengajar beserta perawatan sarana tersebut. Dimensi tangibles ini, terdiri atas: gedung perkuliahan, laboratorium, peralatan bantu pengajaran, kafetaria, sarana olahraga, sarana peribadatan, sarana komunikasi, tempat parkir kendaraan, toilet, dan kamar mandi, bengkel kreativitas mahasiswa dan lain sebagainya.

Hasil perhitungan menunjukkan bahwa tingkat kepentingan atribut ini menurut penilaian mahasiswa adalah sebesar 4,364 sedangkan tingkat kebaikan atribut ini adalah sebesar 2,942. Jadi gap kualitas untuk dimensi ini adalah sebesar -1,422. Jadi hal ini berarti bahwa kualitas pelayanan untuk dimensi ini adalah cukup memuaskan. Hal ini berarti pula bahwa baru sebagian saja atribut, kualitas, layanan dimensi tangible yang dapat dipenuhi.

\subsubsection{Kegiatan Yang harus dilakukan}

Hasil analisis menunjukkan terdapat sejumlah pelayanan akademik dan administrasi yang harus ditingkatkan dan diprioritaskan. Kegiatan-kegiatan yang harus dilkukan untuk meningkatkan kualitas pelayanan kepada mahasiswa adalah sebagai berikut:

\section{Dimensi Assurance}

- Peningkatan perbaikan sikap dari karyawan dan dosen dalam hal kesopanan, keramahan pelayanan, melalui pembinaan mental dan berbagai macam training etika pelayanan.

- Peningkatan mutu dosen dan karyawan melalui studi lanjut, seminar, pelatihan, magang di industri dan lokakarya, serta kegiatan lain yang dapat mengembangkan profesionalisme.

- Membangun kemudahan mahasiswa untuk menemui atau berkonsultasi dengan dosen atau pengelola melalui informasi waktu dan tempat untuk konsultasi.

- Meningkatkan rasa aman bagi mahasiswa dengan cara optimalisasi penjagaan dan pengawasan dari Satuan Pengaman (Satpam) terutama di gedung perkuliahan dan Juru parkir kendaraan.

- Penyempurnaan pelaksanaan ujian TA melalui mekanisme tingkat kompetensi mahasiswa dan team penguji. 


\section{Dimensi Empathy}

- Secara aktif menanggapi / menyelesaikan masalah dan merasakan apa yang dialami mahasiswa khususnya dalan PBM secara tuntas.

- Pelibatan mahasiswa dalam pengambilan keputusan dalam persoalan yang menyangkut kepentingan mahasiswa

- Membangun budaya keterbukaan berfikir secara ilmiah sehingga mahasiswa memilkiki keberanian untuk mengemukakan pendapat dan penghargaan dosen tehadap pendapat mahasisiwa.

- Pembinaan bakat dan kepemimpinan mahasiswa, mengarahkan kegiatan-kegiatan Himpunan Mahasiswa Jurusan (HMJ) ke dalam kegiatan yang bersifat konstruktif dan peningkatan profesionalisme sesuai bidang studinya, seperti: Latihan Dasar Kepemimpinan, Program Kreativitas Mahasiswa (PKM), Penelitian Lomba Karya Inovatif Produktif (LKIP), Mengikuti aneka Lomba/Kompetisi bidang Perawatan dan Perbaikan.

- Menggali Informasi beasiswa dari berbagai sumber

- Menyelenggarakan Bursa Kerja, kerja sama dengan berbagai perusahaan sesuai bidang keahlian.

3. Dimensi Responsiveness

- Penerapan dan penegakan budaya disiplin pengelola, karyawan dan dosen dalam melaksanakan tugasnya.

- Pemantauan aktifitas sehari-hari dalam bentuk absensi elektronik bagi karyawan dan pengelola terutama soal kehadiran dan pulang tepat waktu

- Dibuat kuensioner kehadiran dan kualitas pengajaran bagi pengajar, dimana Ketua Jurusan dapat menindak lanjuti hasil kesioner tersebut sehingga dapat diambil tindakan yang bersifat edukatif bagi semua pihak.

- Pegumuman secara terbuka dan berkala unit pelayanan mana yang di anggap paling cepat dan sikap dalam melakukan pelayanan begitu jugasebaliknya.

\section{Dimensi Reliability}

- Penyempurnakan Proses Belajar Mengajar

- Penjadwalan perkuliahan yang baik,

- Transparansi dan obyektivitas dalam penilaian,

- Keterbukaan sistem birokrasi dan tidak mempersulit mahasiswa

- Penanganan masalah yang cepat dan akurat,

- Sikap dosen, pengelola dan karyawan yang simpatik dan handal dalam memberikan pelayanan kepada mahasiswa.

5. Dimensi Tangible

- Peningkatan pengadaan Peralatan work-shop dan laboratorium yang cukup serta up to date.

- Penyediaan sarana dan prasarana ibadah yang memadai

- Penambahan Peralatan mengajar yang memadai

- Penambahan buku-buku perpustakaan berikut fasilitas dan pelayanan yang memadai
- Penyediaan sistem jaringan informasi onl-line yang memadai dan layanan Internet (hot-spot area) yang bisa kontinu.

- Menjaga kebersihan kamar mandi \& toilet dengan mengoptimalkan karyawan bagian kebersihan secara bergiliran.

- Menyediakan P3-K dan Poliklinik Kesehatan yang memadai.

Terkait dengan perbaikan dan peningkatan kelima dimensi kualitas layanan tersebut diatas, hal terpenting bagi jurusan perawatan dan perbaikan mesin adalah segera mengidentifikasi kekurangan layanan yang diberikan terutama dari keluhan mahasiswa, membantu memecahkan masalah yang dihadapi mahasiswa, mengkomunikasikan kesulitan-kesulitan layanan akademik dan administratif yang dihadapi pihak jurusan, menyelaraskan, menyeimbangkan dan menyempurnakan layanan secara keseluruhan.

\subsubsection{Tingkat Kemudahan Layanan}

Peningkatan kualitas pelayanan di jurusan perawatan dan perbaikan mesin sangat mungkin dilakukan, sebab dilihat dari besaran rasio perbaikan (improvement ratio) kelima dimensi kualitas pelayanan rata-ratanya sebesar 1,188. Hal ini menunjukkan tingkat kesulitan yang dihadapi bersifat sedang, artinya bahwa sumber daya yang dimiliki dapat menunjang peningkatan kualitas pelayanan kepada mahasiswanya.

\subsubsection{Program Peningkatan Pelayanan}

Program pengembangan yang sekarang sedang dan terus diupayakan dilakukan oleh Jurusan perawatan dan perbaikan mesin untuk meningkatkan mutu pelayanan kepada mahasiswa adalah sebagai berikut:

1. Pengembangan kurikulum berbasis stake holder. Program ini didukung kegiatan pelatihan, penelitian, seminar, praktek kerja industri bagi mahasiswa dan dosen.

2. Peningkatan sarana pembelajaran di kelas dan sejenisnya yang mengarah kepada peningkatan unsur tangibles, responsiveness, assurance, realiability, dan empathy.

3. Peningkatan kualitas sistem manajemen jasa pelayanan akademik dan adsministratif melalui pembuatan database yang lengkap yang dapat diakses oleh semua civitas akademis sesuai kebutuhan.

4. Peningkatan efektifitaas pelaksanaan proses belajar mengajar yang ada di Jurusan yang mengarah pada peningkatan terhadap aspek pelayanan reliability, assurance, responsiveness, dan empathy kepada mahasiswa.

5. Membangun komunikasi intensif antar civitas akademik, melaui dialog dosen-mahasiswa (DDM) secara rutin dan berkala sehingga diperoleh masukan tentang aspek-aspek apa yang harus dilakukan oleh Jurusan perawatan dan perbaikan mesin Politeknik Ketapang.

6. Menjalin hubungan yang lebih intens dengan berbagai perusahaan yang diharaapkan dapat menyerap lulusan secara optimal. 


\subsubsection{Kelemahan Metode Servqual dan QFD}

1. Keterbatasan Metode Servqual

Beberapa keterbatasan penerapan Model Servqual di lembaga pendidikan khususnya di Politeknik Ketapang ialah sebagai berikut:

- Cenderung berfokus pada individual dan mengabaikan arti kerjasama dan kebersamaan. Padahal dalam dunia pendidikan hal itu sangat diperlukan.

- Model Servqual menilai kualitas layanan berdasarkan atribut-atribut terukur yang mudah ditetapkan. Padahal kenyataannya dalam dunia pendidikan jasa yang di rasakan melibatkan proses secara keseluruhan mencakup berbagai pengalaman mahasiswa selama kuliah secara lebih komplek dan sulit diukur.

- Model Servqual bersifat out put oriented atas proses jasa yang sesungguhnya dan mengabaikan proses-proses yang mendahuluinya, sehingga seringkali berupa gambaran yang tidak utuh.

2. Keterbatasan Metode QFD

Adapun keterbatasan QFD khususnya dalam penelitian ini adalah sebagai berikut:

- Cenderung bersifat kualitatif yang sebenarnya sulit terukur.

- Hasil analisis kualitas dan tingkat kepentingan atribut layanan diperoleh didasarkan atas dari skor rata-rata.

- Belum sepenuhnya dapat mencerminkan analisis yang sesuai dengan kondisi masing-masing individu yang bersangkutan.

\section{Kesimpulan dan Saran \\ 6.1 Kesimpulan}

Mahasiswa Jurusan perawatan dan perbaikan mesin menaruh harapan sangat besar akan pelayanan yang baik dari lembaga. Tingkat kepuasan mahasiswa terhadap pelayanan akademik dan administratif selama ini sudah cukup baik, tetapi masih ada kesenjangan antara kualitas layanan yang diharapkan dan tingkat kebaikan pelayanan yang diberikan. Diperlukan perbaikan dan peningkatan terhadap kelima dimensi kualitas layanan. Sumber daya yang dimiliki oleh jurusan mampu menunjangnya dengan baik, mengingat improvement ratio berada di ring moderately difficult Improvement.

Adapun prioritas yang harus di lakukan adalah sebagai berikut:

- Dimensi Assurance: peningkatan mutu dosen dan karyawan, pembinaan mental spiritual dan training etika pelayanan, membangun budaya konsultasi bagi mahasiswa, peningkatkan rasa aman bagi mahasiswa, dan penyempurnaan pelaksanaan ujian TA melalui mekanisme tingkat kompetensi mahasiswa dan tem penguji.

- Dimensi Empathy: aktif menanggapi / menyelesaikan masalah PBM yang dialami mahasiswa, pelibatan mahasiswa dalam pengambilan keputusan soal kepentingan mahasiswa, membangun budaya keterbukaan berfikir secara ilmiah, pembinaan bakat dan kepemimpinan mahasiswa, menggali Informasi beasiswa dan mengadakan bursa kerja secara rutin dan berkala.

- Dimensi Responsiveness: penerapan budaya disiplin berbagai pihak, pemberlakuan absensi elektronik bagi karyawan, kuensioner kehadiran dosen dan kualitas pengajaran, komunikasi antar civitas akademik, pembuatan database yang lengkap dan mudah diakses setiap saat.

- Dimensi Reliability: penyempurnaan PBM secara berkelanjutan, pengembangan kurikulum berbasis stake holder, peningkatan sarana - prasarana pembelajaran, penjadwalan perkuliahan yang baik, kehadiran dosen dan ketepatan waktu mengajar, transparansi dan obyektivitas dalam penilaian, sistem birokrasi yang terbuka dan tidak mempersulit mahasiswa, penanganan masalah yang cepat dan akurat serta bersikap simpatik dan handal.

- Dimensi Tangible: peningkatan pengadaan peralatan work-shop dan laboratorium yang cukup dan up to date, penyediaan sarana dan prasarana ibadah yang memadai, penambahan peralatan mengajar yang memadai, penambahan buku-buku perpustakaan berikut fasilitasnya, penyediaan sistem jaringan informasi onl-line dan hot-spot area yang kontinu, menjaga kebersihan kamar mandi \& toilet dengan mengoptimalkan karyawan bagian kebersihan secara bergiliran, menyediakan P3-K dan poliklinik kesehatan yang memadai.

\subsection{Saran-Saran}

- Untuk dapat memperoleh nilai prioritas perbaikan yang mendekati sebenarnya, sebaiknya dalam proses penyusunan kuesioner dan pengolahannya memperhitungkan bobot kepentingan dari setiap item pernyataan yang diberikan.

- Bagi yang tertarik melakukan penelitian penerapan Servqual dan QFD di perguruan tinggi, selain memperhitungan bobot juga akan lebih baik jika difokuskan pada lembaga pemakai perguruan tinggi tersebut. Silakan mencoba.

\section{DAFTAR PUSTAKA}

Alma Buchari.2008. Metode dan Teknik Penyusunan Tesis. Alfabeta Bandung

Ciptono, Wakhid Slamet, 1999. Kajian Strategi ISO 9001/9002 untuk Program Studi Manajemen Fakultas Ekonomi Universitas Gajahmada Yogyakarta. PPS-UNDIP Semarang.

Crow, Kenneth. "Customer-Focused Development with QFD." DRM Associates.Fall2006.30Aug.2006. <http://www.npdsolutions.com/qfd.html>.

Cohen, Lou (1995). Quality Function Deployment: how to make QFD work for you. Addison-Wesley Publishing Company, Reading, MA.41-50.

Jogiyanto.2008. Pedoman Survei Kuesioner.BPFE UGM.

Kai Yang.(2008). Voice of The Customer Capture and Analysis. Mc Graw Hill.NewYork

Kotler, P. 2000. Marketing Management. Millenium edt. Prentice Hall Int. Upper Sadle River. New Jersey 
Revelle B.Jack..; et.al. 1998. The QFD Handbook. John Wiley and Sons.New York.

Santoso, Eko Budi, M. Maskan. 2007, Penerapan Quallity Functional Deployment (QFD) Guna Peningkatan Pelayanan Mahasiswa Politeknik Ketapang, Studi Kasus Jurusan Tata Niaga, Penelitian Dosen Muda Politeknik Ketapang

Supranto J.2006. Pengukuran Tingkat Kepuasan Pelanggan. Rineka Cipta Jakarta.

Tjiptono, Fandy 2008. Service Management. Yogyakarta : Andi Offset

Tjiptono, Fandy, 2004, "Prinsip-Prinsip Total Quality Service”, penerbit Andy Offset: Yogyakarta. 